11. Даний законопроект перебував на розгляді Верховної Ради України, проте його скасовано. Вважаємо за доцільне все ж таки прийняти даний нормативно правовий акт (Див.: Євграфова Є. Законопроект про нормативно-правові акти: парламентсько-президентська практика). URL : http://www.justinian.com.ua/article.php?id=3117.

12. Кодекс про адміністративні правопорушення.

13. Закон України Про вибори народних депутатів України від 17.11.2011 № 4061-VI. URL : http://zakon2.rada.gov.ua/laws/show/4061-17.

14. Бабінова О.О. Критерії оцінки ефективності діяльності органів місцевого самоврядування: світовий досвід та Україна. Стратегічні пріоритети. № 2(3). 2007 р. С. 77.

15. Закон України «Про охорону атмосферного повітря» від 16.10.1992 № 2707-XII. URL : http://zakon2.rada.gov.ua/laws/show/2707-12.

16. Закон України «Про стимулювання розвитку регіонів» від 08.09.2005 № 2850-IV. URL : http://zakon4.rada.gov.ua/laws/show/2850-15.

УДК 340.15

DOI https://doi.org/10.32844/2618-1258.2019.3-1.8

ДОБКІНА К.Р.

\title{
ІСТОРІЯ СТАНОВЛЕННЯ ТА РОЗВИТКУ ІНСТИТУТУ УЧАСТІ В ЦИВІЛЬНОМУ СУДОЧИНСТВІ ДЕРЖАВНИХ ОРГАНІВ: ЗАГАЛЬНОТЕОРЕТИЧНИЙ АСПЕКТ
}

Наукова стаття присвячена дослідженню історії становлення та розвитку інституту участі в цивільному судочинстві державних органів. 3 урахуванням комплексного аналізу визначено, що окремі риси правового захисту чужих інтересів, були притаманні українському цивільному судочинству за часів Російської імперії. Головним чином це проявлялося у діяльності спеціально створюваних органів 3 нагляду за дотриманням усіма місцевими органами влади законів щодо захисту майнових, фінансових інтересів держави.

3'ясовано, що після судової реформи 1864 року захист чужих прав отримав якісно-новий напрямок. Діяльність прокурорів у цивільному процесі була розширена деякими категоріями справ та виходила за рамки цивільних позовів, адже додатково охоплювала захист прав та законних інтересів окремих громадян. Статут цивільного судочинства відносив до такої діяльності справи щодо окремих категорій громадян: неповнолітніх, безвісно відсутніх, недієздатних осіб, а також окремі цивільні справи щодо шлюбних відносин.

Відповідно до норм Кодексу про акти громадянського стану 1918 р. органам державної влади надавалося право звертатися до суду із позовом щодо позбавлення батьківських прав, а для захисту інтересів непрацездатних громадян у суді передбачалося створення та функціонування відділів соціального забезпечення. Окрім того, житлово-санітарні інспекції, які здійснювали нагляд за житловими приміщеннями в сфері виконання санітарних правил, повинні були сприяти у правильному вирішенні справ про розселення у житлові приміщення незабезпечених груп населення.

Доведено, що цивільно-процесуальне законодавство 20-х років XX століття містило лише форми участі у цивільному процесі прокурора, водночас, форми звернення до суду інших органів державної влади, які мали б на меті відстоювати права та законні інтереси держави та окремих громадян не знайшли свого відображення у ЦПК УСРР 1924 року, хоча норми матеріального права передбачали окремі права органів державної влади по захисту прав та законних інтересів інших осіб у цивільному судочинстві.

Ключові слова: ичвільне судочинство, органи державної влади, органи прокуратури, радянське законодавство, УСРР.

() ДОБКІНА К.Р. - кандидат юридичних наук, доцент, декан юридичного факультету (Державний університет інфраструктури та технологій) 
The scientific article is devoted to the study of the history of formation and development of the institute for participation in civil proceedings of state bodies. Taking into account the complex analysis, it was determined that certain features of the legal protection of other people's interests were inherent in the Ukrainian civil proceedings during the Russian Empire. This was mainly manifested in the activities of specially created bodies to supervise the observance of laws of all local authorities on the protection of the property and financial interests of the state.

It is found that after the judicial reform of 1864 , the protection of alien rights has taken a qualitatively new direction. Prosecutors' activity in the civil process has been expanded in some categories of cases and went beyond civil lawsuits, since it additionally covered the protection of the rights and legitimate interests of individual citizens. The Statute of Civil Procedure referred to the following activities in the case of certain categories of citizens: minors, missing persons, incapacitated persons, as well as individual civil cases concerning marital relations.

In accordance with the provisions of the Civil Code Act of 1918, public authorities were given the right to sue their parents for deprivation of parental rights, and for the protection of the interests of incapacitated citizens, the court provided for the establishment and functioning of social security departments. In addition, housing and health inspections that supervised housing in the area of compliance with sanitary rules should assist in the proper resolution of cases of displacement into the premises of unsecured population groups.

It is proved that the civil procedural legislation of the $1920 \mathrm{~s}$ contained only forms of participation in the civil process of the prosecutor, at the same time, forms of appeal to the court of other bodies of state power, which were aimed at defending the rights and legitimate interests of the state and individual citizens. reflected in the Civil Code of the Ukrainian SSR in 1924, although substantive law stipulated separate rights of public authorities to protect the rights and legitimate interests of others in civil court

Key words: civil judiciary, public authorities, prosecution bodies, soviet legislation, USSR

Постановка проблеми. Завдання науки цивільного процесуального права, як і будь-якої іншої науки, не обмежується вивченням різних категорій та понять, наприклад, цивільних процесуальних правовідносин й суміжних інститутів. Використовуючи загальні методи діалектики, вона покликана розкривати причини, які зумовили їх появу або подальшу модифікацію, 3 тим, щоб зрозуміти, який сенс закладений в той чи інший правовий інститут, в тому числі, вдосконалювати його з метою найбільшої ефективності функціонування. У правничо-наукових дослідженнях, які стосувалися проблематики участі у цивільному судочинстві органів державної влади та місцевого самоврядування, не приділялося особливої уваги причин появи даного інституту, з точки зору, історико-правового аспекту, що особливо актуально в період реформування цивільного судочинства.

Стан дослідження. Органи державної влади як учасники цивільного судочинства в тій чи іншій мірі були предметом дослідження в роботах різних вчених, серед значної кількості радянських дослідників, необхідно відзначити найбільш відомих: М.В. Муравйова, А.Ф. Коні, О.В. Васьковського, С.Ю. Кац, О.Г. Маліцького тощо. Історико-методологічні аспекти становлення розвитку та становлення інституту участі у цивільному судочинстві органів державної влади вченими не досліджувалося.

Метою статі є дослідження історії становлення та розвитку інституту участі в цивільному судочинстві державних органів.

Виклад основного матеріалу. У науці цивільного процесуального права України відсутні наукові дослідження інституту захисту у цивільному процесі інтересів приватних осіб, або держави починаючи за часів перебування України у складі Російської імперії. Водночас, справедливо буде зазначити, що окремі риси правового захисту чужих інтересів, все ж, були притаманні цивільному судочинству Російської імперії. Головним чином це проявлялося у діяльності спеціально створюваних органів з нагляду за дотриманням усіма місцевими органами влади законів щодо захисту майнових, фінансових інтересів держави.

Вперше, такий спеціальний орган з'явився у 1722 році, коли Указом від 12 січня Петром I було засновано прокурорський нагляд у Російській імперії. Його діяльність носила адміністра- 
тивний характер аж до видання Катериною II 07 листопада 1775 року Закону, відповідно до якого при губернських прокурорах створювалася посада стряпчих, які здійснювали, поряд 3 виконанням адміністративних обов'язків, функцію участі в суді у кримінальних і цивільних справах. Власне до цього історико-правового періоду і відноситься перша згадка про можливість судового захисту чужих, переважно державних, інтересів. Стряпчі у цивільних справах, іменовані «казенними стряпчими», займалися тільки тими справами, які не стосувалися приватних інтересів кожного громадянина окремо, але стосувалися державних інтересів, в першу чергу, майнових. Правовий статус стряпчих за головним своїм призначенням характеризувався правами та гарантіями притаманних позивачам у цивільних справах [1, с. 266].

Після судової реформи 1864 року захист чужих прав отримав якісно-новий напрям. Діяльність прокурорів у цивільному процесі була розширена деякими категоріями справ та виходила за рамки цивільних позовів, адже додатково охоплювала захист прав та законних інтересів окремих громадян. Статут цивільного судочинства відносив до такої діяльності справи щодо окремих категорій громадян: неповнолітніх, безвісно відсутніх, недієздатних осіб, а також окремі цивільні справи щодо шлюбних відносин. Крім цього, прокурори продовжували брати участь у справах, пов'язаних з інтересами скарбниці або земських установ, міських і сільських товариств, але їх участь обмежувалася, головним чином, лише дачею висновків по справі. Пред’явлення позовів з метою захисту інтересів окремих громадян не входило в коло службових повноважень прокурора, що відповідало принципам цивільного і цивільного процесуального права дореволюційних часів. У цивілістичній науці того часу панував підхід «автономії особистості», який полягає в тому, що ніхто, в тому числі і держава, не має права втручатися в особисте життя людини, виходячи з природи приватних прав, що характеризуються винятковістю, держава не має права втручатися і в сферу приватної власності окремого громадянина [2, с. 79].

Одночасно з розширенням в законодавстві сфери участі прокуратури в цивільному процесі в цивілістичній науці розгорілися суперечки з приводу доцільності їх участі у процесі. Більшість цивілістів виступали за обмеження діяльності прокуратури участю лише в рамках кримінального судочинства, відстоюючи при цьому позицію, за якої даний орган повинен був займатися публічним кримінальним переслідуванням, наглядом за розслідуванням злочинів і підтриманням обвинувачення на суді. Були й такі вчені, які хоча і визнавали в якості основної функції прокуратури ії діяльність в галузі кримінального процесу, але все ж вважали за доцільне залишити за прокурором право брати участь в цивільному процесі з метою дачі висновку по деяким чітко визначеним категоріям цивільних справ.

У результаті суперечок 9 травня 1911 року було прийнято закон, який скасував можливість участі прокурора по більшості цивільних справ. Згідно ст. 343 Статуту цивільного судочинства зазначалося, що висновок прокурора має бути обов'язково наданий та представлений по таким категоріях цивільних справ як: спори між судовими і урядовими установами; спори щодо підроблення документів; шлюбно-сімейні спори; спори щодо стягнення грошових коштів із судових відомств [3, с.47].

Таким чином, з урахуванням вищевикладеного можна зробити висновок, що дореволюційне цивільно-процесуальне законодавство містило в собі лише певні прояви участі у цивільному судочинстві органів державної влади, а саме - прокуратури, що обмежувалося лише обов'язком направленням висновку по цивільній справі.

Новий етап розбудови інституту участі у цивільному судочинстві органів державної влади розпочинається після прийняття у 20 -х роках XX століття нового цивільного законодавства. Зокрема, прийнятий у 1922 році Цивільний кодекс Української РСР поєднував в собі синтез двох граней соціалістичної (капіталістичної) моделі: з одного боку, закріплювалася свобода господарської діяльності (можливість громадян вільно обирати рід професій і занять, займатися промисловою та торгівельною діяльністю), а із іншого - переважна більшість статей кодифікованого акту містила пріоритет державних інтересів над приватними. Наприклад, держава надавала правовий захист тільки тим цивільним правовідносинам, які не конкурували із державними інтересами, а принцип «можна все, що дозволено» застосовувався лише щодо захисту прав та законних інтересів держави [4, с. 74$]$.

У сфері цивільного судочинства втручання держави в цивільні правовідносини знаходило своє відображення у вигляді діяльності суб'єктів, які можуть виступати від свого імені в захист чужих прав та законних інтересів у цивільному судочинстві. Вже, в перших актах радянської влади, присвячених питанням здійснення правосуддя, розширювалося коло осіб, повноважних на пред’явлення позовної заяви до суду з метою порушення провадження по цивільній справі, 
зокрема у Положенні «Про народний суд», затвердженого Декретом ВЦВК 30 листопада 1918 року до таких суб'єктів були віднесені особи, які не мають своєї суб'єктивної зацікавленості у справі $[5$, с. $25 ; 6]$.

Незважаючи на прагнення радикально змінити правове регулювання існуючих відносин, державою була впроваджена ідея створення спеціального органу - прокуратури, яка б здійснювала універсальну діяльність пов'язану із наглядом за станом законності. На час розробки власної радянської концепції принципів побудови і діяльності прокуратури функції нагляду за дотриманням законності і охорони чужих прав були покладені на окремі органи державної влади. Відповідно до норм Кодексу про акти громадянського стану 1918 року органам державної влади надавалося право звертатися до суду із позовом щодо позбавлення батьківських прав, а для захисту інтересів непрацездатних громадян у суді передбачалося створення та функціонування відділів соціального забезпечення. Окрім того, житлово-санітарні інспекції, які здійснювали нагляд за житловими приміщеннями в сфері виконання санітарних правил, повинні були сприяти у правильному вирішенні справ про розселення у житлові приміщення незабезпечених груп населення.

Форми участі прокурора в цивільному процесі, знайшли своє відображення у прийнятому в 1924 році ЦПК УСРР. Прокурору надавалося право розпочати цивільне провадження шляхом пред'явлення цивільного позову, а також гарантувалося право вступати у вже розпочатий судовий процес на будь-якій стадії, якщо, на його думку, цього вимагала охорона інтересів держави і трудящих мас [7, с. 70].

Повноваження прокурора з нагляду за станом законності, захисту чужих прав і інтересів носили універсальний характер, не обмежувалися якими-небудь окремими областями чи сферами народного господарства. При виборі справи, в якій необхідною була його участь, він керувався своїм внутрішнім переконанням. У той же час з огляду на особливу важливість окремих категорій справ законодавство не надавало можливості вирішення питання необхідності участі на власний розсуд, а містило імперативні норми. Зокрема, Циркуляр від 25 жовтня 1926 р № 193 вказував на необхідність звертати увагу на зростання заборгованості по заробітній платі і в справах, де йдеться про заборгованість групі трудящих, обов'язково брати участь у справах, підтримуючи позовні вимоги. Прокурорські працівники зобов'язані були незалежно від скарг і заяв окремих громадян, спостерігати за ходом і правильним розглядом тих цивільних справ, де предметом позову було розірвання кабальних і невигідних угод [8].

Директивний лист «Про роботу прокуратури по захисту найманої праці у селі» передбачав необхідність частіше практикувати пред’явлення позовних заяв прокурорами у справах про розірвання кабальних трудових угод. Докладний перелік категорій справ, на які прокуратура повинна була приділити особливу увагу і в яких прокурори повинні були брати участь шляхом пред'явлення позову містився в Інструктивному листі Прокуратури СРСР «Про роботу органів прокуратури у цивільних справах» від 2 грудня 1940 р № 204/8.

Крім прямої вказівки на певні категорії спорів, законодавчо вироблялися критерії, якими прокуратура повинна була керуватися при вирішенні питання про необхідність участі в справі. В якості таких критеріїв, як правило, виділяли наявність у справі матеріального інтересу держави; аспекти необхідності опіки над громадянами з боку держави; особливе політичне значної окремої категорії цивільної справи.

На практиці прокуратура найбільш часто брала участь у цивільному судочинстві в справах, які зачіпали інтереси державних установ, підприємств, кооперацій, сільськогосподарських колективів щодо захисту соціально-слабких груп із числа трудящих (сиріт, інвалідів праці та війни та ін.); в справах про визнання недійсними протизаконних угод, які ведуть до явного збитку для держави; у справах по угодах, укладених в обхід закону; в справах про вилучення певних будівель; в справах по угодах, укладених під впливом крайньої потреби тощо [9].

3 позиції прийнятого раніше законодавства, розуміння юридичної зацікавленості органів державної влади як учасників спірних правовідносин, виходило із буквального і систематичного тлумачення окремих процесуальних норм, оскільки державні органи могли брати участь у цивільній справі лише в одній із передбачених процесуальним законодавством форм, вибір яких залежав від характеру їх зацікавленості, а також цілей вступу до розгляду справи.

По-перше, як учасники матеріальних правовідносин, органи державної влади могли вступати у вже розпочатий між позивачем та відповідачем процес для захисту своїх суб'єктивних матеріальних інтересів в якості третіх осіб, які заявляють самостійні вимоги на предмет спору. У випадках, коли вимоги державних підприємств і установ не виключали вимоги позивача, вони могли посісти процесуальне становище співпозивача. 
По-друге, державні підприємства та установи, могли брати участь у розгляді та вирішенні цивільної справи, не маючи самостійних вимог на предмет спору. Перебуваючи в певних правовідносинах з однією із сторін і побоюючись, що несприятливе рішення для останньої може вплинути на його права або обов'язки по відношенню до позивача або відповідача, вони могли вступити в процес в якості пособника однієї зі сторін, з метою допомогти їм виграти спір. У цьому випадку вони займали становище третіх осіб, які не заявляють самостійних вимог на предмет спору.

Таким чином, будучи учасниками спірних матеріальних правовідносин та володіючи юридичним інтересом у вирішенні спору, ці суб'єкти могли вступати в розпочатий із ініціативи інших осіб процес і займати процесуальне становище співпозивача чи третьої особи.

Висновки. Таким чином, історія становлення та розвитку інституту участі в цивільному судочинстві державних органів датується дореволюційним законодавством, якому були відомі лише окремі риси цього інституту. Зазначені закономірності проявлялися у захисті органами державної влади в цивільному судочинстві чужих прав та законних інтересів. Яскравим свідченням окресленої тенденції є участь прокурора у цивільному процесі для дачі висновків по спорах, які торкалися державних інтересів та/або інтересів окремих громадян, перелік яких містився у чинному законодавстві.

Закріплення в радянському законодавстві інституту участі органів державної влади як учасників цивільного судочинства було об'єктивно обумовлено комплексом політико-економічних і соціальних причин. Водночас, цивільно-процесуальне законодавство 20-х років XX століття містило лише форми участі у цивільному процесі прокурора, який міг порушувати провадження по справі шляхом пред'явлення позову, або вступити у вже розпочатий процес на будь-якій стадії, якщо, на його думку, цього вимагала охорона інтересів держави і трудящих мас.

Форми звернення до суду інших органів державної влади, які мали б на меті відстоювати права та законні інтереси держави та окремих громадян не знайшли свого відображення у ЦПК УСРР 1924 року, хоча норми матеріального права передбачали окремі права органів державної влади по захисту прав та законних інтересів інших осіб у цивільному судочинстві.

\section{Список використаних джерел:}

1. Васьковский Е.В. Курс гражданского процесса. Т. 1. М., 1913. 624 с.

2. Абрамов С.Н. «Гражданский процесс». М., 1948. 483 с.

3. Васьковский Е.В. Учебник гражданского процесса. Изд. 2-е. М., 1917327 с.

4. А.Г. Зуев «Прокурор в гражданском суде». // Журнал Министерства Юстииии. 1911. № 1. С.74-94.

5. Козлов Ю.М. «Органы советского государственного управления». Юр. Лит. М., 1960. 314 с. 6. Декрет СНК РСФСР от 18 июня 1919 г. «О санитарной охране жилищ». // Хронологическое собрание Законов, Указов Президиума Верховного Совета РСФСР и Постановлений Правительства РСФСР 1917- 1927 г2. Т. 1. М., 1949. С. 68-69.

7.Кац С.Ю. Участие прокуратуры в советском гражданском процессе / С.Ю. Кац. Харьков, $1958.395 \mathrm{c}$.

8. Циркуляр НКЮ «Об усилении работы прокуратуры по общему надзору» от 17 декабря 1928 г.// Еженедельник Советской Юстииии. 1928. № 46-47.

9. Циркуляр от 07 апреля 1936 г. № 25/ 22 «О работе прокуратуры по гражданским делам». // Сборник Приказов прокуратуры Союза ССР. 1939, с. 193-195. 